\title{
Concept for Common European TV Channel
}

\author{
Slavinski A. \\ Draganov I. \\ New Bulgarian University -Sofia,Bulgaria
}

\begin{abstract}
One of the problems, which lies ahead of the EU and the European Integration is how can people from different nationalities learn more about each other. In this problem, there is a severe lacking of progress. Thus, in light of European's people natural desire of better understanding and successful collaboration in the advancement of common European values, comes the need of a Pan-European TV channel. TV PanEurope+ will help in an effective way for the common understanding of the history, the culture, the tourism, the customs of the European people.
\end{abstract}

Keywords: mutual understanding; cultural variety; Paneuropian TV channel; missing audiovisual face of EC, increase the understanding of the European elections significance.

\section{Introduction}

Two important questions bother us.

To what extend do we know the cultural variety of the peoples in the European Unity and from where and how do we form our notion?

And how do the other European peoples envisage the Bulgarians?

We very often witness malevolence, lack of mutual understanding, inaccuracy which does irritate us. These are usually the things, which happen when someone is an object of somebody else's retelling. Even more so when this story retold is a product of relayed information. In television the report "a priori" contains some sort of a retelling of particular events and as such it carries the personal take of its author. What do the TV channels do? As general rule, they broadcast the current information of their correspondents and in a didactic way they teach what the EU is. The slogan "This is the way it is in Europe!" has reached a mantra status. But in Europe there is a big diversity. Nevertheless, a big deficit exists on global level. Eleven years ago, the Leader of the Negotiating Team for Bulgaria on the part of the European Commission Mrs. Brigitte Chernota gave us the advice to showcase more often the positive contemporary Bulgarian people. The important question is how they can become known not only to the European administration, but to the European peoples as well. Precisely in this we can find an empty niche.

We do know what is happening in Japan, USA, Iraq, Afghanistan and so many other places, but we lack information about Slovenia, Croatia, Iceland, Denmark, Norway, Estonia and so on. Not even to mention Cyprus and Malta. The International Information Agencies and Radio Stations has become one giant mechanism, reducing the information. The mechanically operating international editors of the Bulgarian televisions are no different. What then? How are we then to understand more, meaning, to draw closer, to get to know and start appreciating each other with the Portuguese, Spanish, Swedish, Irish and the rest of the European peoples?

\section{Preconditions and means for resolving the problem}

Ahead of us lies an immense deficit. In the context of the mutual desire of all the European countries and peoples to understand each other more fully and to build up a common value system, it won't be hard to notice the lack of one common PanEurope+ TV channel. A channel similar to BBC, but for the European Union. A supreme model of European digital public TV. 
PanEurope+ channel would have to produce its own information for the European Institutions during the day and for the rest of the time to broadcast programme submitted by the different national public television channels form all the European countries and independent producers. The TV PanEurope+ channel can be developed on the foundation of the already existing EUROPE BY SATELITE, which gives institutional information about the activity of the EU and EC broadcasted by satellite.

In the future, the channel would have to produce its own information for its daily programme and for the rest of the time to broadcast programme submitted by the different television channels /as a start submitted by the national public televisions/ from all the European countries and independent producers. These will be programmes produced and aired by its national public TV stations.

Each country will select and send its own programme once per month. The programmes will be collected in the studio of EUROPE BY SATELITE in Brussels and will be transmitted from there. The digitalization eliminates the problem with the limited resourses. This means that it shouldn't be difficult each country to allot a frequency for the PanEurope+ TV channel. The programme will consists of different panels of information covering common European topics. The national programmes will be produced by each country member of the EU and the countries candidates for membership in the union.

For example - the morning block "Good morning Europe" will broadcast the news of the day from Brussels, Strasbourg, the work of the commissions, departments, Council of Europe, European Court of Human Rights, PACE and other prominent European institutions.

A second block will present the economical information, service information /the weather, etc for the whole Europe/, information of utmost importance in the circumstances of the looming financial crisis.

A third block will broadcast the news from the European capitals and news about the relationships between the country members and information for the currency, energy, labor market, refugees, and merchandise exchange in Europe.

The two hour block will be repeated two times during the time period from 06.00 until 10.00 o'clock.

After 10.00 o'clock the programme will consists of movies and abundant cultural, science, educational, entertainment, youth, religious and ethnical programmes from all the different countries, focusing on the integration. The programme needs to present the cultural differences in one attractive way and not to be enigmatic in their representation of the peoples. The unknown is still frightening, but the globalization above all in the domain of the electronic mass media, unifies and depersonalizes, rather then to support the variety. Willingly or unwillingly whole army of editors is reducing the information received, forming it according to its own personal notions. For example, Japan is always the country of the high technology, tea ceremonies, the seppuku and similar cliché. Is Japan only that? That is a rhetorical question.

The evening programme will be set aside for gala programme of the different country members. This will include concerts of symphonic, jazz, pop, rock and other genres of music, opera, theater, movies, exhibitions, youth programmes. What is entertaining for other nations, what makes them laugh, what touches them, how do they study and work, what are their cultural messages - all these are questions of utmost importance for all Europeans.

Central part will have the programmes for the historical, cultural and custom varieties of the different peoples and ethnical minorities.

TV programme dealing with the problems product of the communication differences, the problems with the different requirements encountered by the travelers through the countries of the $\mathrm{EU}$, the common and extremely hard problems connected with the migrants, traffic of women and drugs, the struggle with organized crime etc... Information like this is needed and I would say of vital importance for the future of the European Union, but regrettably this type of information is missing.

This channel /PanEurope+ channel/ will be the main cultural forum for common understanding of the European peoples.

The night programme will be the time for the big concerts, premiere movies, theater plays, and film-portraits of the great personalities from different countries, which took part in the European development. 
TV channel PanEurope+ will help for effective cultural exchange and sharing of our different values. The differences will be reduced as a result of the integration around the common European values. There won't be anymore need for the different countries to try to guess what the others mean, and this is the most important outcome of it. No one could retell about the other peoples. Everyone could tell personal about himself.

It will be a cultural forum, a crossing point for the cultural variety and its immediate apperception. At the later stage on the analogy of TV ARTE this common channel become into place for film,s, teatriacal and musical europeans coproductions. TV PanEurope+ will be the place for gathering idea,s of makers, producers and distributors from different europeans nationalities. The targets of this later stage is the coproduction, $s$ full force advance of the investigation of cases; the documentaries and future films, theatrical, operas and ballet dancing performances.

TV PanEurope+ will become not only the audiovisual face, but the spirit of united Europe. For the present EU not possess suchlike.

TV PanEurope+ will increase the tourism in the europians countries.

The TV channel can solve one more problem. Everybody knows that the level of participation of the voters for the elections for the European parliament is low in each European country - sometimes as low as $20 \%$. We hope that TV channel PanEurope + will increase the understanding of the European elections significance and will additional motivate European citizens for the elections of members for the European parlament.

\section{Conclusion}

\section{In short, PanEurope+ will be the audiovisual face of United Europe. Up until now this face is still missing.}

The most important is that by the help of PanEurope+ channel the different ethnicities will come out of their anonymity and many preconceived notions will die out, notions which often are the reason for ill-founded and irrational animosity. The people will take part in the common political debates on European level and become active citizens. Through the means of this channel people will break trough the narrow, outdated frame of the $20^{\text {th }}$ century classical country and applying their positions and interests will be able to naturally integrate themselves.

Only then we will be able to give answer to the questions for the information's quality, the stable development of the trend for adopting the European values and their implementation on local level, from all the peoples, not only the Bulgarians.

The integral programme of TV channel PanEurope+ will adopt the working model of ARD, FRANCE 3 and EURONEWS. In this way it won't be too financially burdensome, but it will be only matter of organization and composition of the programme...

\section{4 .Expenses}

The TV studio complex and the satelite transmitter "EUROPE BY SATELITE" are available. No more investistions are needed for now. The TV studio complex and the satellite transmitter "EUROPE BY SATELITE" will broadcast every day TV programme from different European country. This programme will be kept available for viewing online.

The programme will be sent in its original language and subtitled in English. The most professional approach is the program to be translated to the respective language with a subtitlinprogram.

This could happen in every country, which will translate the programme in advance on the official languages of the EU. The countries will receive the translated programme from the central server. The programme will be sent a month before its broadcasting, which will define its lasting nature. As we already said, the different countries will show already prepared TV programme and the translation is purely a technological problem, easily solved with English subtitles. This, however, may cause a feeling of cultural inequality.

It should be mentioned that the translation program EMITEX, from "Screen electronics" is already in development and in several years time will be likely able to translate simultaneously and automatically unlimited ammount of text.

\section{Literature.}

"TV programming in the general audiovisual context" - Draganov I. New Bulgarian University press, 2012 
P.S. During the years 1993 and 1994, Mrs Elena Tomalevska-Tsankova, selected, translated and organized the broadcasting of 10 hour Bulgarian TV programme through the French channel TV 5, represented under the title The day of Bulgaria on TV 5. Our production was watched by many people and was accepted very cordially. Regrettably after a change of the BNT's executives, the new one declined to support Elena's excellent initiative further. What remains is the two years of good practice. What could stand on the way of multiplying this experience and carry it on pan European level?

\section{Reference}

[1] Draganov I. , 'The TV programming in the general audiovisual context', NBU, Sofia, 2012, p 170-177./ 